\begin{tabular}{c|c|c}
\hline \hline & MARINE ECOLOGY PROGRESS SERIES \\
Vol. 233: 307-310, 2002 & Mar Ecol Prog Ser & Published May 21 \\
\hline \hline
\end{tabular}

NOTE

\title{
Preliminary reports from the Caulerpa taxifolia invasion in southern California
}

\author{
Susan L. Williams*, Edwin D. Grosholz \\ Department of Environmental Science and Policy and Bodega Marine Laboratory, University of California at Davis, PO Box 247, Bodega Bay, \\ California 94923-0247, USA
}

\begin{abstract}
We report the first preliminary in situ observations of the invasive strain of the tropical green seaweed Caulerpa taxifolia in Huntington Harbor, California. Although patch size had regressed from the previous, presumably summer, extent, C. taxifolia exhibited new frond growth within patches despite low winter water temperature. The growth patterns, size of fronds, density, and biomass were similar to those reported from other invasion sites in the Mediterranean Sea and Australia. The seagrass Ruppia maritima also grew at the site. In patches mixed with C. taxifolia, the biomass of $R$. maritima was 20 times lower than in patches without C. taxifolia.
\end{abstract}

KEY WORDS: Invasive species · Caulerpa taxifolia $\cdot$ Ruppia maritima

Resale or republication not permitted without written consent of the publisher

In June 2000, the Mediterranean invasive strain of Caulerpa taxifolia was identified at 2 sites in southern California (Jousson et al. 2000). Since it was first discovered in the Mediterranean Sea in 1984, this invasive seaweed has continued to expand its range in the Mediterranean and Adriatic Seas (Meinesz 1999). It is considered a major ecological threat to native marine biodiversity (Académie des Sciences 1997) and one of the top 100 invasive species on earth (IUCN The World Conservation Union: http://www.issg.org/booklet.pdf). C. taxifolia is not native to the west coast of the USA (Abbott \& Hollenberg 1976, Stewart 1991) or Baja California (Dawson 1944, Zertuche-González et al. 1995). The closest natural population of $C$. taxifolia occurs in Hawaii (Magruder \& Hunt 1979).

Here we report preliminary observations made on 29 and 30 January 2001 in 1 of 2 ponds ('west pond', 33.72862 N, 118.06669 W digital degrees) infested by Caulerpa taxifolia at Huntington Harbor, Orange County, 1 of 2 invaded sites in southern California. Our observations were necessarily opportunistic and limited because access to $C$. taxifolia eradication sites in California was restricted, was difficult to arrange, and coincided with storm events that limited underwater

*E-mail: slwilliams@ucdavis.edu visibility to ca. $40 \mathrm{~cm}$. Our objectives were to observe the growth habit of $C$. taxifolia, without interfering with the eradication program underway (Anderson \& Keppner 2001), and to make broad comparisons with C. taxifolia in other invasions. Although hardly exhaustive, our measurements of biomass, size structure, and density of $C$. taxifolia in Huntington Harbor are the only such data available from the western hemisphere.

The date when Caulerpa taxifolia first invaded Huntington Harbor is unknown, although an anecdotal account suggests C. taxifolia was present in 1998 (S. Murray pers. comm.). By summer 2000, C. taxifolia had become established in 2 artificial ponds created within a waterfront housing development adjacent to the main harbor. The ponds are largely concrete enclosures, each approximately 1.2 ha in surface area, and are surrounded by houses and lawns. Circulation is provided artificially by pumping seawater through culverts between the ponds and the main harbor. The maximum depth of the west pond is $3 \mathrm{~m}$.

Materials and methods. Using SCUBA, we searched the pond benthos for Caulerpa taxifolia. We then sampled the areas covered by $C$. taxifolia to characterize the $C$. taxifolia canopy. We counted the number of upright primary fronds and stolon meristems of $C$. taxifolia in $25 \times 25 \mathrm{~cm}$ quadrats $(\mathrm{n}=4)$ haphazardly tossed into vegetated areas. A primary frond, which can branch into secondary fronds, was delineated by a single insertion point on the horizontal stolon. We removed above and below ground vegetation in additional quadrats ( $\mathrm{n}=10$ with $C$. taxifolia, $\mathrm{n}=5$ with the seagrass Ruppia maritima) and counted the number of primary fronds and stolon meristems. We measured frond widths (widest point) and lengths from the insertion point on the stolon to the tip of the longest frond and compared these with canopy height measurements in the field. After removing sediments and epiphytes, we weighed C. taxifolia and $R$. maritima samples after drying at $70^{\circ} \mathrm{C}$. We could not extrapolate to biomass in the pond because data on coverage were not available, nor could we estimate it due to time constraints and poor visibility. 
Table 1. Comparison of Caulerpa taxifolia between invasion and native (New Caledonia) sites. $95 \%$ confidence interval (CI) provided for Huntington Harbor data. Dimensions are for live material, except for Cap Martin (herbarium material). Data are mean \pm standard deviation (SD) with number in parentheses. nd: no data

\begin{tabular}{|c|c|c|c|c|}
\hline Site & Reference & $\begin{array}{l}\text { No. primary } \\
\text { fronds } \mathrm{m}^{-2}\end{array}$ & $\begin{array}{c}\text { Biomass } \\
\text { (g dry wt } \mathrm{m}^{-2} \text { ) }\end{array}$ & $\begin{array}{l}\text { Mean length } \\
\text { (cm) }\end{array}$ \\
\hline $\begin{array}{l}\text { Huntington Harbor } \\
95 \% \text { CI }\end{array}$ & This study & $\begin{array}{c}1478 \pm 1296(14) \\
\pm 42 \mathrm{CI}\end{array}$ & $\begin{array}{l}102 \pm 97(10) \\
\pm 60 \mathrm{CI}\end{array}$ & $\begin{array}{l}10.4(197) \\
\pm 0.53 \mathrm{CI}\end{array}$ \\
\hline Moreton Bay, Australia & Pillen et al. (1998) & $\begin{array}{l}4138 \pm 1370(\mathrm{nd}) \\
\text { in dense patches }\end{array}$ & $86 \pm 7.2(\mathrm{nd})$ & $6 \pm 3.1(\mathrm{nd})$ \\
\hline Cap Martin, France & Meinesz et al. (1995) & 5100 to $13920(14)$ & 500 (nd) & mostly $<20$ \\
\hline Elba Island, Italy & Ceccherelli \& Cinelli (1998) & $\begin{array}{l}250 \text { to } 2700 \\
\text { (4 monthly) }\end{array}$ & nd & 3 to 16 \\
\hline New Caledonia & Garrigue (1994) & $\leq 37(\mathrm{nd})$ & 1836 (nd) & 2 to 10 \\
\hline
\end{tabular}

Results and discussion. Caulerpa taxifolia grew in discrete patches in the soft clay sediments in 2 to $3 \mathrm{~m}$ water depth in Huntington Harbor. The salinity was $34 \%$ (R. Woodfield pers. comm.). We found 3 major patches with smaller patches $(20 \times 20 \mathrm{~cm})$ scattered around the major patches. Visibility was too poor to measure the size of major patches, but they were estimated to be over several meters in diameter. The smaller patches apparently had receded from their former extent because, swimming away from their perimeters, we found single thalli, then decomposed thalli at a maximum of $150 \mathrm{~cm}$ from the perimeter, then mud. Although the water temperature was 10 to $12^{\circ} \mathrm{C}$, which limits the growth of the invasive strain of C. taxifolia (Komatsu et al. 1997), some frond tips exhibited new growth within the patches. We also observed over 20 unattached fragments of $C$. taxifolia consisting of stolons with fronds and rhizoids intertwined in the canopy.

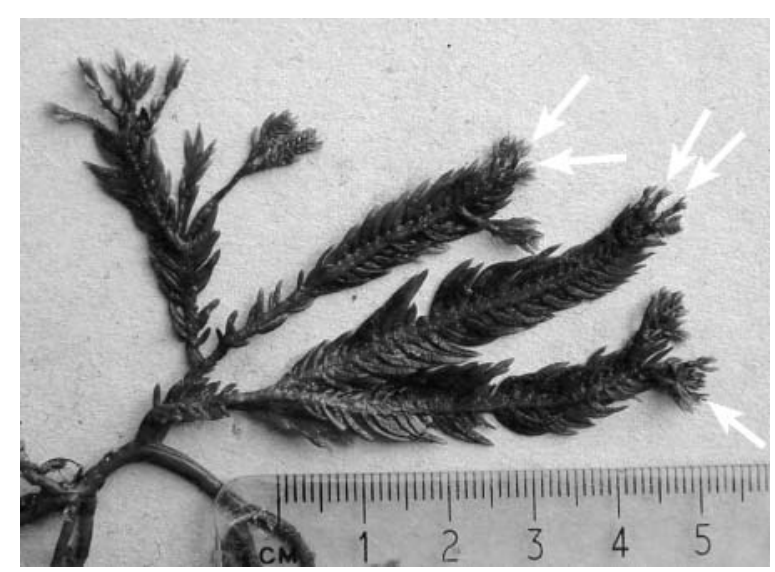

Fig. 1. Portion of a frond of Caulerpa taxifolia with many proliferative tips. Arrows point to several examples. Scale in $\mathrm{cm}$
The biomass, frond density, and size of Caulerpa taxifolia from different invasion sites are similar (Table 1). Although not all mean or extreme values from other sites fell within the $95 \%$ confidence intervals for the Huntington Harbor means, we do not want to overinterpret results based on small samples collected in different manners, seasons, habitats, and invasions of different ages. Instead, we focus on new observations and point out that there is a paucity of published data for quantitative comparisons.

Caulerpa taxifolia exhibited growth strategies typical for the genus Caulerpa (Williams et al. 1985, Smith \& Walters 1999) that enable the various species to propagate prolifically. For example, upright fronds had developed adventitious rhizoids and stolons when lying decumbent on sediments, and stolons when entwined within the canopy. Rhizoids growing down from a stolon pillar generated fronds at the distal end. One growth feature not previously observed in any Caulerpa species was the profuse production of proliferations (Fig. 1) arising from upright primary fronds and higher order branches, with a radial arrangement of branchlets, which are typically planar on native $C$. taxifolia. A frond had to achieve a minimum length of $1.5 \mathrm{~cm}$, but typically $4.5 \mathrm{~cm}$, to develop proliferations. We assume that these proliferations produce higherorder branches. The number of primary fronds of $C$. taxifolia (240 to $4046 \mathrm{~m}^{-2}$ ) was within the range exhibited at other invasion sites (Table 1 ). If $20 \%$ of primary fronds (including branches) had $>5$ proliferative tips (Fig. 2A) and they produced secondary branches, a very dense canopy could develop.

The mean \pm standard error (SE) number of stolon meristems was $555 \pm 182 \mathrm{~m}^{-2}(\mathrm{n}=10)$. We believe this is the first account of meristem density for an invasive population of Caulerpa taxifolia. This high meristem density highlights the potential for proliferation both across the sediment and by growing upwards and over 

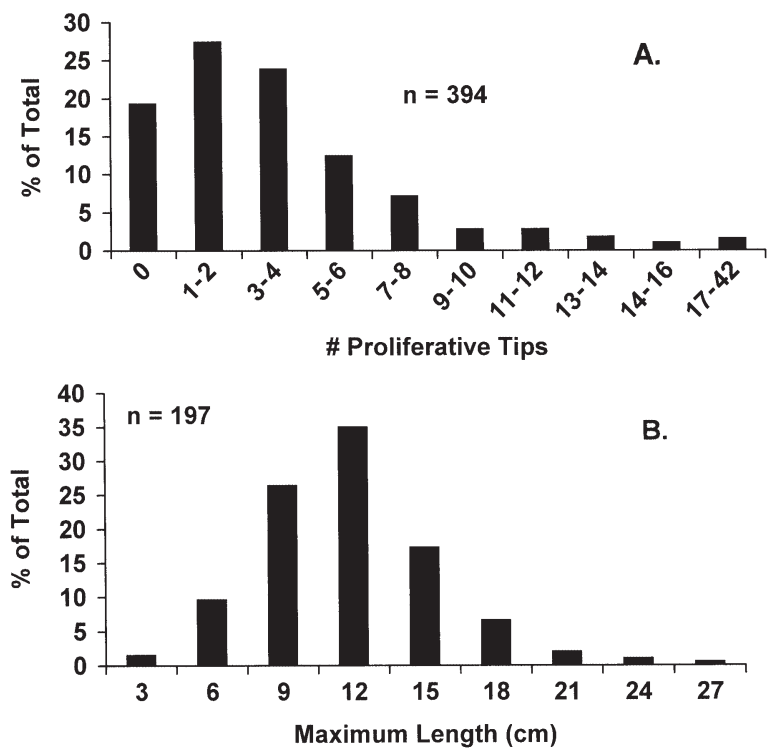

Fig. 2. (A) Frequency histogram of number of proliferative tips per primary frond and branches $(\mathrm{n}=394)$ of Caulerpa taxifolia. (B) Frequency histogram (3 cm size classes) of frond length as a percentage of the total for 197 fronds of C. taxifolia

other organisms. The stolon meristems of various species of Caulerpa, including $C$. taxifolia in its native habitat (S. L. Williams unpubl. data from St. Croix, U.S. Virgin Islands) and the invasive Mediterranean strain, can grow at least $1 \mathrm{~cm} \mathrm{~d}^{-1}$ in the field $\left(\mathrm{O}^{\prime} \mathrm{Neal}\right.$ \& Prince 1982, Williams et al. 1985, Williams \& Dennison 1990, Boudouresque 1997). Stolon growth rates together with meristem density provide a basis for modeling spread rates.

Gigantism is considered a characteristic of the genetically differentiated aquarium strain of Caulerpa taxifolia (Jousson et al. 2000, Wiedenmann et al. 2001). Fronds of C. taxifolia in its native habitats are reported to grow to $15 \mathrm{~cm}$ (Taylor 1972, Magruder 1979, Garrigue 1994, Littler \& Littler 2000), but means and variances have not been reported. Published data on the mean size of the invasive $C$. taxifolia do not greatly exceed $15 \mathrm{~cm}$ (Table 1), although the maximum size can be up to $60 \mathrm{~cm}$ (Meinesz et al. 1995). The majority of the C. taxifolia fronds in Huntington Harbor were within the size range in the native habitat (Fig. 2B), but the longest frond was $24.6 \mathrm{~cm}$. By proliferating over the top of the highest-order branches, C. taxifolia attained a mean canopy height of at least $20 \mathrm{~cm}$ in Huntington Harbor. The mean \pm standard deviation (SD) frond width was $1.36 \pm 0.38 \mathrm{~cm}$ (maximum $2.1 \mathrm{~cm}, \mathrm{n}=76$ ), with $70 \%$ of the fronds $<1.8 \mathrm{~cm}$. Frond width data are not available for other populations. The entire genus is notorious for remarkable morphological plasticity in response to the environment (Jaubert \& Meinesz 1981, Carruthers et al. 1993, Meinesz et al. 1995, Ceccherelli
\& Cinelli 1999, Collado-Vides \& Robledo 1999). Frond size-frequency data from native and other invasive populations would be useful for a rigorous assessment of population differences. If found, such differences could be the result of genetic differentiation in the aquarium-invasive strains, morphological plasticity in response to the environment, or some other factor, e.g. differences in epiphytes, pathogens, or grazers.

Ruppia maritima, a submerged aquatic vascular plant protected under the USA Clean Water Act, grew over large areas of the study pond, a feature of the invaded habitat not previously reported. $R$. maritima provides important habitat for waterfowl (Kantrud 1991), which were present in the invaded ponds at Huntington Harbor. Most, but not all, of the R. maritima had a collapsed, senescent canopy of flowering shoots, its typical winter state in southern California (S. L. Williams et al. unpubl. data). Caulerpa taxifolia grew intermingled with $R$. maritima in some of these patches. In the non-senescent patches sampled, the biomass of $R$. maritima was reduced where it grew with C. taxifolia compared with where it grew alone (Fig. 3); the 95\% confidence intervals for the biomass means did not overlap. Although our data are few and correlative, lower seagrass biomass in the presence of C. taxifolia is consistent with the observations that $C$. taxifolia is overgrowing the native seagrass (Zostera marina) in Agua Hedionda, California (R. Woodfield pers. comm.) and that it can outcompete native seagrasses in the Mediterranean (Ceccherelli \& Cinelli 1997, 1998, 1999). If this is true, then C. taxifolia,

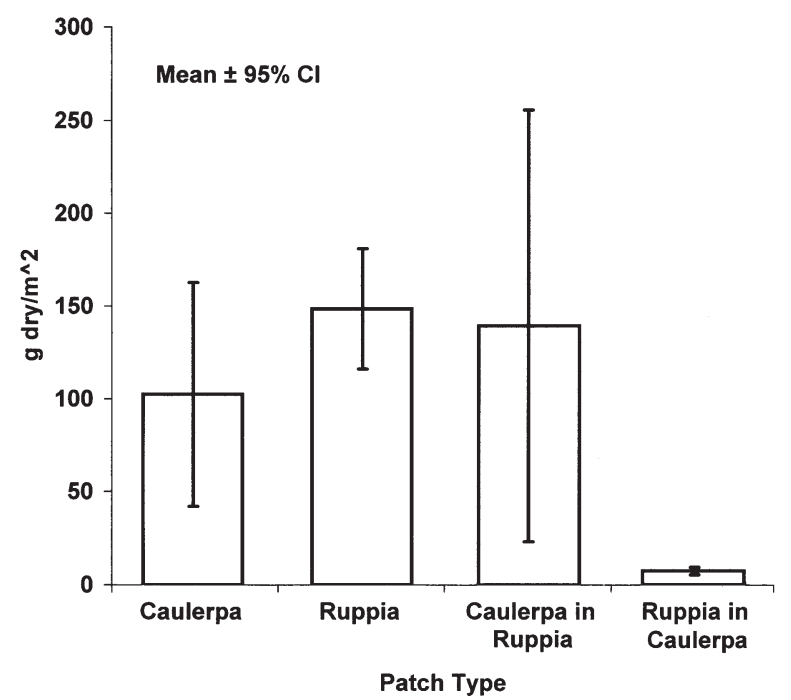

Fig. 3. Biomass (dry wt) for single species patches (Caulerpa taxifolia, Ruppia maritima) and in mixed species patches $(C$. taxifolia in $R$. maritima, $R$. maritima in $C$. taxifolia) patches. Bar height and error bar represent the mean and $95 \%$ confidence interval $(\mathrm{CI})$ for each patch type $(\mathrm{n}=10 \mathrm{C}$. taxifolia, $\mathrm{n}=5 R$. maritima, $\mathrm{n}=2$ mixed species) 
together with Musculista senhousia and Bunodeopsis sp., forms a trio of non-native species having deleterious effects on native seagrasses in southern California (Reusch \& Williams 1998, 1999, Williams \& Heck 2001).

\begin{abstract}
Acknowledgments. Contribution 2162 from Bodega Marine Laboratory, University of California at Davis. The California Department of Food \& Agriculture and the Southern California Caulerpa Action Team permitted sampling. Rachel Woodfield of Merkel and Associates and Marc Doalson of the Santa Ana Regional Water Quality Control Board arranged the logistics of site access and sampling. Bruce Nyden assisted with diving and sampling. This study was funded by grant \#NA66RG0477 R/CZ-62PD to S.L.W. from the California Sea Grant College Program and support funds from the Division of Agriculture and Natural Resources of the University of California to E.D.G. The reviews herein are those of the authors and do not necessarily reflect those of National Oceanic and Atmospheric Administration (NOAA) or any of its subagencies. The US Government is authorized to reproduce and distribute this article for governmental purposes.
\end{abstract}

\section{LITERATURE CITED}

Abbott IA, Hollenberg GJ (1976) Marine algae of California. Stanford University Press, Stanford

Académie des Sciences, France (1997) Dynamique d'espèces marine invasives: application a l'expansion de Caulerpa taxifolia en Méditerranée. Technique \& Documentation, Paris

Anderson LWJ, Keppner S (2001) Caulerpa taxifolia: marine algal invader provokes quick response in U.S. waters. Aquat Nuisance Species Digest 4:21-23

Boudouresque CF (1997) Dynamique des populations de Caulerpa taxifolia en Méditerranée, y compris les mécanismes de la compétition interspécifique. In: Dynamique d'espèces marine invasives: application a l'expansion de Caulerpa taxifolia en Méditerranée. Technique \& Documentation, Paris, p 145-162

Carruthers TJB, Walker DI, Huisman JM (1993) Culture studies on two morphological types of Caulerpa (Chlorophyta) from Perth, Western Australia, with a description of a new species. Bot Mar 36:589-596

Ceccherelli G, Cinelli F (1997) Short-term effects of nutrient enrichment of the sediment and interactions between the seagrass Cymodocea nodosa and the introduced green alga Caulerpa taxifolia in a Mediterranean bay. J Exp Mar Biol Ecol 217:165-177

Ceccherelli G, Cinelli F (1998) Habitat effect on spatiotemporal variablility in size and density of the introduced alga Caulerpa taxifolia. Mar Ecol Prog Ser 163:289-294

Ceccherelli G, Cinelli F (1999) Effects of Posidonia oceanica canopy on Caulerpa taxifolia size in a north-western Mediterranean bay. J Exp Mar Biol Ecol 240:19-36

Collado-Vides L, Robledo D (1999) Morphology and photosynthesis of Caulerpa (Chlorophyta) in relation to growth form. J Phycol 35:325-330

Dawson EY (1944) Marine algae of the Gulf of California. University of Southern California Press, Los Angeles

Garrigue C (1994) Biomasse et répartition de Caulerpa taxifolia dans les lagons de Nouvelle-Calédonie. Oceanol Acta 17:563-569

Jaubert J, Meinesz A (1981) Light-dependent growth forms of Caulerpa urvilliana Montagne in the lagoon of the atoll of

Editorial responsibility: Otto Kinne (Editor),

Oldendorf/Luhe, Germany
Takapoto (French Polynesia). Proc 4th Int Coral Reef Symp 2:425-429

Jousson O, Pawlowski J, Zaninetti L, Zechman FW and 5 others (2000) Invasive alga reaches California. Nature 408: $157-158$

Kantrud HA (1991) Wigeongrass (Ruppia maritima L.): a literature review. Fish Wildl Res 10:1-58

Komatsu T, Meinesz A, Buckles D (1997) Temperature and light responses of alga Caulerpa taxifolia introduced into the Mediterranean Sea. Mar Ecol Prog Ser 146:145-153

Littler DS, Littler MM (2000) Caribbean reef plants. Offshore Graphics, Washington, DC

Magruder WH, Hunt JW (1979) Seaweeds of Hawaii. The Oriental Publishing Co, Honolulu

Meinesz A (1999) Killer algae. University of Chicago Press, Chicago

Meinesz A, Benichou L, Blachier J, Komatsu T, Lemee R, Molenaar H, Hari X (1995) Variations in the structure, morphology and biomass of Caulerpa taxifolia in the Mediterranean Sea. Bot Mar 38:499-508

O'Neal SW, Prince PJ (1982) Relationship between seasonal growth, photosynthetic production and apex mortality of Caulerpa paspaloides (Chlorophyceae). Mar Biol 72:61-67

Pillen TL, Ingeltaube P, Dennison WC (1998) Are expanding populations of the tropical green alga Caulerpa taxifolia a potential threat for Moreton Bay? In: Tibbetts IR, Hall NJ, Dennison WC (eds) Moreton Bay and catchment. School of Marine Science, University of Queensland, Brisbane, p 327-328

Reusch THB, Williams SL (1998) Variable response of native eelgrass Zostera marina to a non-indigenous bivalve Musculista senhousia. Oecologia 113:428-441

Reusch THB, Williams SL (1999) Macrophyte canopy structure and the success of an invasive marine bivalve. Oikos 84:398-416

Smith CM, Walters LJ (1999) Fragmentation as a strategy for Caulerpa species: fates of fragments and implications for management of an invasive weed. PSZN Mar Ecol 20: $307-319$

Stewart JG (1991) Marine algae and seagrasses of San Diego County. California Sea Grant College Report \#T-CSGCP020. University of California at San Diego, La Jolla

Taylor WR (1972) Marine algae of the eastern tropical and subtropical coasts of the Americas. The University of Michigan Press, Ann Arbor

Wiedenmann J, Baumstark A, Pillen TL, Meinesz A, Vogel W (2001) DNA fingerprints of Caulerpa taxifolia provide evidence for the introduction of an aquarium strain into the Mediterranean Sea and its close relationship to an Australian population. Mar Biol 138:229-234

Williams SL, Dennison WC (1990) Light availability and diurnal growth of a green macroalga (Caulerpa cupressoides) and a seagrass (Halophila decipiens). Mar Biol 106: $437-443$

Williams SL, Heck K Jr (2001) Seagrass communities. In: Bertness M, Gaines S, Hay M (eds) Marine community ecology. Sinauer Associates, Sunderland, p 317-337

Williams SL, Breda VA, Anderson TW, Nyden BB (1985) Growth and sediment disturbance of Caulerpa spp. (Chlorophyta) in a submarine canyon. Mar Ecol Prog Ser 21:275-281

Zertuche-González JA, Pacheco-Ruiz I, González-González J (1995) Macroalgas. In: Fisher W, Krupp F, Schneider W, Sommer C, Carpenter KE, Niem VH (eds) Guía FAO para la identificación de especies para los fines de la pesca. Pacifico Centro-Oriental. I. Plantas e invertebrados. FAO, Roma, p 10-82

Submitted: September 29, 2001; Accepted: January 28, 2002 Proofs received from author(s): April 24, 2002 